efficiency." "This level-90 dB-is not at all unusual in industry, but it is very much higher than the level which people often complain about in offices and other places away from the factory floor." As is common experience, undue noise makes normal conversation impossible; it is in fact difficult unless the noise is reduced well below the $90 . \mathrm{dB}$ level. $60 \mathrm{~dB}$ is considered a more reasonable level, but in an office environment, where ordinary speech is involved, the limits of noise should be much lower.

The question of noise in all its aspects, but particularly as a hazard in industry, is now a matter of national importance. It is indeed gratifying to learn that the Ministry of Pensions and National Insurance has sponsored a large-scale research project into certain aspects of occupational deafness. This is the joint problem of the Medical Research Council and the National Physical
Laboratory. "The purpose of this study is to monitor hearing of people exposed to industrial noise . . . to establish the relation between noise and damage to hearing ... to make recommendations concerning hearingconversation measures." When it is commonly roalized that effects of prolonged noise, in whatever environment, above a certain level, are real, and provocative of perman. ent deafness, then people may begin to take those precautions which common sense (and this booklet) suggest. Apart from this, undue and unwanted noise, especially when it intrudes into social life, public or private, without let or hindrance, is a form of annoyance which many people will not tolerate. The recent ban on transistor radio sets operating in some of Britain's royal parks is a step in the right direction. but only a beginning.

\section{H. B. Milner}

\title{
THE LISTER INSTITUTE
}

\begin{abstract}
$\mathrm{HE}$ annual report of the Governing Body of the Lister Institute ${ }^{*}$ is necessarily a greatly condensed account of the varied activities of 'The Lister', and it is impossible to indicate in a brief notice the scope and detail of the research involved. The report summarizes the Institute's work under several headings.

In the field of microbiology, work continues on the genetics of bacteria, particularly Salmonella spp., with special regard to the transmission of drug resistance; on the specificity of the antigens of Trypanosoma brucei and $T$. vivax, and on the conditions governing the formation of capsules by the anthrax bacillus in vitro. The Institute's field studies on trachoma in the Gambia continue, together with work on the epidemiology and pathology of pleuropnexumonia-like organisms and of the Shope fibroma virus in cell culture. There has been continued progress in making a non-infectious smallpox vaccine and in work on the purification of vaccinia virus and antibody immunity in vaccinia and variola infections.

Among the epidemiological studies was an important investigation, carried out in co-operation with the Malaria Fradication Division of the World Health Organization and the Veterinary Services of Southern Rhodesia, of identification tests of the blood meals of tsetse flies and Anopheles mosquitoes.

Immunopathological investigations are being carried out on a factor in anaphylactic tissues which induces eosinophilia; on the local production in the cervix uteri of antibodies lethal to spermatozoa, and on improvement of therapeutic antitoxins to scorpion bites.

$T$. brucei, which had not boen previously cultured for any prolonged period, has been successfully established in a liquid medium which makes it available for immunological and biochemical studies. Other work includes investigations of the immunology of whooping cough and typhoid and the mechanism of infection with actinomycotic dermatitis of sheep. The section devoted to the physiology

* The Lister Institute of Preventive Medicine. Report of the Governing Body, 1964. Pp. 37. (London: The Lister Institutc of Preventive Medicine,
1964.)
\end{abstract}

of bacteria includes studies of the somatic polysaceharides of S. and R. Salmonella and the chemistry of the flagellar proteins of Salmonella.

Biophysical work includes work on human plasma proteins and on the molecular eharacterizations of bloodgroup substances. The latter has led to extension and modification of existing theories for interpreting sedimentation and viscosity data. The Blood Products Laboratory continued to prepare dried plasma and plasma fractions for the National Health Service, and the Blood Group Research Unit has continued to study the $\mathrm{Xg}$ and the $\mathrm{Rh}$ systems. The Blood Group Reference Laboratory continues its work in its now building north of the Biophysies Department.

The report records the conferment of a baronetcy on the chairman of the Institute's Governing Body, Sir Charles Dodds, and the elections of Lord Iveagh and Lord Brain, both members of the Governing Body, to fellowship of the Royal Society. The death during the year of R. St. John Brooks, curator for more than 20 years of the National Collection of Type Cultures, is a great loss to the Institute and to microbiology in general. The director of the Institute, Prof. A. A. Miles, has been appointed Biological Secretary and a vice-president of the Royal Society of London. During the year the Guinness chair of microbiology was established at the Institute and Dr. B. A. D. Stocker was appointed to it.

A gift of $£ 30,000$ from the Fleming Memorial Fund for Medical Research will enable the Institute to establish its cun dectron-microscope unit. The new Virus Laboratory at Elstroe was completed during the year and occupied by the Virus Research Unit, and the Library at Chelsea was enlarged by the addition of another room.

The report also records the lectures given by the staff in Europe and America, and concludes with a list of their numerous publications.

For details of the biochemical work on blood-group substances, cellular phospholipids and glycogen the report itself must be consulted.
G. LAPAGE

\section{MOUSE ANTIBODY PRODUCTION TEST FOR THE ASSAY OF THE MOLONEY VIRUS}

\author{
By Dr. EVA KLEIN and Prof. GEORGE KLEIN \\ Department of Tumour Biology, Karolinska Institutet Medical School, Stockholm
}

NOCULATION of homografts, sub-threshold isografts
or tissue homogenates derived from mouse lymphomas
induced by the Moloney virus leads to specific transplanta-
tion resistance against subsequent Moloney lymphoma isografts. The serum of resistant mice contains humoral antibodies, demonstrable in three different ways: by passive transfer of transplantation resistance, by cytotoxicity for Moloney lymphoma cells in vitro in the 